\title{
Molecular cloning and characterization of a novel pyrethroid-hydrolyzing esterase originating from the Metagenome Gang $\mathrm{Li}^{\dagger}$, Kui Wang ${ }^{\dagger}$ and Yu Huan Liu*
}

\author{
Address: State Key Laboratory of Biocontrol, School of Life sciences, Sun Yat-sen University, Guangzhou, 510275, PR China \\ Email: Gang Li - lsslig@mail.sysu.edu.cn; Kui Wang - uk0829@126.com; Yu Huan Liu* - lsslyh@mail.sysu.edu.cn \\ * Corresponding author †Equal contributors
}

Published: 30 December 2008

Microbial Cell Factories 2008, 7:38

This article is available from: http://www.microbialcellfactories.com/content/7///38

(C) $2008 \mathrm{Li}$ et al; licensee BioMed Central Ltd.

This is an Open Access article distributed under the terms of the Creative Commons Attribution License (http://creativecommons.org/licenses/by/2.0), which permits unrestricted use, distribution, and reproduction in any medium, provided the original work is properly cited.
Received: 27 October 2008

Accepted: 30 December 2008

\begin{abstract}
Background: Pyrethroids and pyrethrins are widely used insecticides. Extensive applications not only result in pest resistance to these insecticides, but also may lead to environmental issues and human exposure. Numerous studies have shown that very high exposure to pyrethroids might cause potential problems to man and aquatic organisms. Therefore, it is important to develop a rapid and efficient disposal process to eliminate or minimize contamination of surface water, groundwater and agricultural products by pyrethroid insecticides. Bioremediation is considered to be a reliable and cost-effective technique for pesticides abatement and a major factor determining the fate of pyrethroid pesticides in the environment, and suitable esterase is expected to be useful for potential application for detoxification of pyrethroid residues. Soil is a complex environment considered as one of the main reservoirs of microbial diversity on the planet. However, most of the microorganisms in nature are inaccessible as they are uncultivable in the laboratory. Metagenomic approaches provide a powerful tool for accessing novel valuable genetic resources (novel enzymes) and developing various biotechnological applications.
\end{abstract}

Results: The pyrethroid pesticides residues on foods and the environmental contamination are a public safety concern. Pretreatment with pyrethroid-hydrolyzing esterase has the potential to alleviate the conditions. To this end, a pyrethroidhydrolyzing esterase gene was successfully cloned using metagenomic DNA combined with activity-based functional screening from soil, sequence analysis of the DNA responsible for the pye3 gene revealed an open reading frame of 819 bp encoding for a protein of 272 amino acid residues. Extensive multiple sequence alignments of the deduced amino acid of Pye 3 with the most homologous carboxylesterases revealed moderate identity (45-49\%). The recombinant Pye3 was heterologously expressed in E. coli BL2 I (DE3), purified and characterized. The molecular mass of the native enzyme was approximately $3 \mathrm{I} \mathrm{kDa}$ as determined by gel filtration. The results of sodium dodecyl sulfate-polyacrylamide gel electrophoresis and the deduced amino acid sequence of the Pye 3 indicated molecular mass of $31 \mathrm{kDa}$ and $31.5 \mathrm{kDa}$, respectively, suggesting that the Pye 3 is a monomer. The purified Pye3 not only degraded all pyrethroid pesticides tested, but also hydrolyzed $\rho$-nitrophenyl esters of medium-short chain fatty acids, indicating that the Pye 3 is an esterase with broader specificity. The $\mathrm{K}_{\mathrm{m}}$ values for trans-Permethrin and cis-permethrin are $0.10 \mu \mathrm{M}$ and $0.18 \mu \mathrm{M}$, respectively, and these catalytic properties were superior to carboxylesterases from resistant insects and mammals. The catalytic activity of the Pye3 was strongly inhibited by $\mathrm{Hg}^{2+}, \mathrm{Ag}^{+}, \rho$-chloromercuribenzoate, whereas less pronounced effect was observed in the presence of divalent cations, the chelating agent EDTA and phenanthroline.

Conclusion: A novel pyrethroid-hydrolyzing esterase gene was successfully cloned using metagenomic DNA combined with activity-based functional screening from soil, the broader substrate specificities and higher activity of the pyrethroid-hydrolyzing esterase (Pye3) make it an ideal candidate for in situ for detoxification of pyrethroids where they cause environmental contamination problems. Consequently, metagenomic DNA clone library offers possibilities to discover novel bio-molecules through the expression of genes from uncultivated bacteria. 


\section{Background}

Pyrethroids and pyrethrins are widely used insecticides. Natural pyrethrins are compounds with insecticidal activity extracted from chrysanthemum flowers. Pyrethroids are synthetic compounds similar in structure to pyrethrins, which have been modified over the years to enhance their insecticidal activity and/or their persistence in the environment [1]

Pyrethroids are likely to become more widely used as organophosphate insecticides including diazinon and chlorpyrifos are phased out due to the concerns regarding their safety [2]. Extensive applications not only result in pest resistance to these insecticides, but also may lead to environmental issues and human exposure. A variety of personnel are exposed to pyrethroids during manufacture and application, diet, and drinking water. Although these compounds are widely considered safe for humans [3], numerous studies have shown that very high exposure to pyrethroids might cause potential problems to man [4]. Such effects include suppressive effects on the immune system, endocrine disruption, lymph node and splenic damage, and carcinogenesis [5]. In addition, most synthetic pyrethroids possess apparent toxicity to fish and other aquatic organisms, including aquatic invertebrates, often at concentrations less than $1 \mu \mathrm{g} \mathrm{L}^{-1}$ [6]. Therefore, it is important to develop a rapid and efficient disposal process to eliminate or minimize contamination of surface water, groundwater and agricultural products by pyrethroid insecticides.

Bioremediation strategies have potential for eliminating or reducing these residues. One such strategy would use enzymes to degrade the pesticide residues, for example, in bioreactors through which contaminated water could be passed, or in washing solutions after post-harvest disinfestation of fruit, vegetables or animal products to reduce residue levels and withholding times [1]. Suitable enzymes for degrading pesticide residues include hydrolases from bacteria, vertebrates and insecticide resistant insects [7-9].

Carboxylesterases represent a group of highly variable and multifunctional hydrolytic enzymes. They have potential for use in the hydrolysis and synthesis of important ester compounds of pharmaceutical, food, biochemical, and biological interests. Some pyrethroid carboxylesterases from pyrethroid-resistant insects have been purified and characterized [8]. Some pyrethroid-degrading bacteria including Bacillus cereus SM3 [9], Pseudomonas Fluorescens [10], Vibrio hollisae, Burkholderia picketti, and Erwinia carotovora have been isolated from soils and rivers [11], The only pyrethroid-degrading enzyme from Bacillus cereus SM3 was purified and characterized. These studies have indicated that the first step in the microbial degradation and detoxifiction of pyrethroid compounds is the hydro- sis of carboxylester linkage, and demonstrated that these enzymes differ in substrate specificity, sensitivity to inhibitors, activation by metals and molecular mass. In a word, this method only focuses on the culturable portion of microorganisms. In fact, most microorganisms have not been researched due to limitations in culturing microorganisms, it is estimated that more than $99 \%$ of microorganisms are thought to be unculturable or difficult to culture in any given environment using standard cultivation methods and therefore not accessible as a source for finding useful biomolecules [12,13]. In order to search for new or improved bioactive products, the development of metagenomic technologies over the past few years has provided access to much of the prokaryotic genetic information available in environmental samples, independent of culturability [14]. Through metagenomic cloning, some genes encoding metagenomic lipases and esterases have been identified in metagenomic libraries from different environmental samples such as soil, water, thermal environment and deep-sea hypersaline anoxic basin [15$18]$.

In this report, we constructed a metagenomic library from vegetable soil for the isolation by functional expression screening of plasmid clones with esterase activity. Several clones with esterase activity were detected, and a novel pyrethroid-hydrolyzing esterase with higher activity and broader substrate specificities was selected for further characterization including thermal stability, optimal temperature and substrate specificity. To our knowledge, this is the first report so far on information about pyrethroidhydrolyzing esterase gene from the unculturable bacterial genome. Further study is helpful to obtain excellent detoxifying enzyme for use as bioremediation agents.

\section{Results \\ Construction of a metagenomic library and screening of a novel esterase gene}

The prokaryotic DNA for metagenomic library, which was used in all experiments, was extracted from vegetable soil. A novel soluble esterase of Pye 3 on an activity based strategy was designed. To test the quality of the library, 100 clones were randomly selected, and the recombinant plasmids were prepared. The average insert size was $4.2 \mathrm{~kb}$, and sizes ranged from 3 to $8 \mathrm{~kb}$. Out of approximately 93,000 colonies, 6 clones were identified by their bright blue color. The metagenomic library represented about $390 \mathrm{Mb}$ of soil microbial community DNA. From these clones, the plasmids were isolated, purified and transformed to fresh E. coli TOP10 cells, all colonies turned blue again and the hydrolysis of pyrethroid was further tested. The ability of the only one positive blue colonies $E$. coli TOP10 (pZP6) to hydrolyze pyrethroid was confirmed by GC-MS analysis. Therefore, pZP6 was subjected to further analysis. The size of cloned fragment in plasmid pZP6 

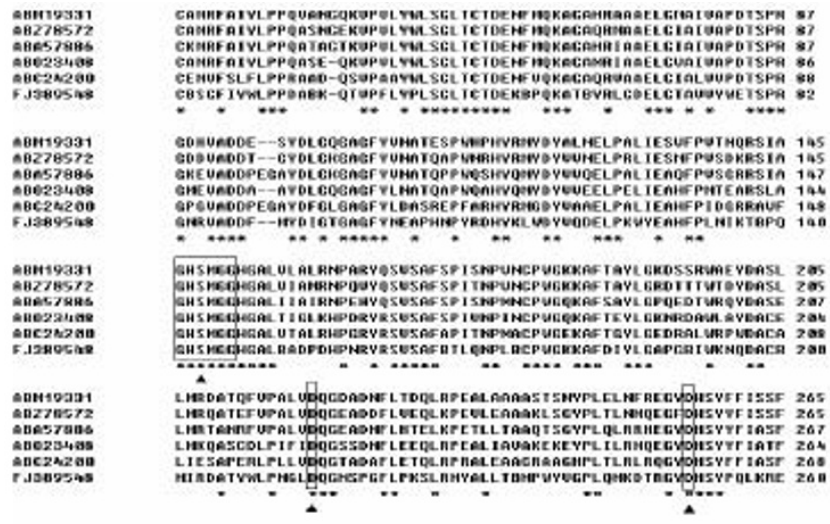

Figure I

Multiple alignment of the partial Amino acid sequences containing the conserved motifs of GxSxG and putative catalytic triad resides of esterases. Except for Pye3, other protein sequences were retrieved from GenBank under following accession numbers: our metagenome (FJ389548), Marinobacter aquaeolei VT8 (ABM1933I), Shewanella halifaxensis HAW-EB4 (ABZ78572), Nitrosococcus oceani ATCC 19707 (ABA57886), Shewanella loihica PV-4 (ABO23408), Rhodospirillum rubrum ATCC I I I 70 $(\underline{A B C 24200})$. The alignment was carried out using the Clustal $W$ method. The open boxes indicate amino acid resides belonging to the putative catalytic triad resides, triangles denote the active site. The same amino acid resides are marked by $(*)$.

was reduced when the fragment was digested with various restriction enzymes, and the deletion derivatives were screened according to pyrethroid-hydrolyzing esterase activity, resulting in the subclone E. coli TOP10 (pZP6-3). The sequence analysis indicated that the pyrethroidhydrolyzing esterase activity was attributed to a $2.6-\mathrm{kb}$ EcoRI fragment. The sequence analysis of the insert DNA showed the presence of one open reading frame (ORF) 819 bp, encoding a polypeptide of 272 amino acids with a predicted molecular mass $(\mathrm{Mr})$ of $31.15 \mathrm{kDa}$.

\section{Sequence analysis of pyrethroid-hydrolyzing esterase}

A blast search in the databases of NCBI revealed that the Pye showed moderate identity (45-49\%) at the amino acid level with several carboxylesterases from Shewanella loihica PV-4 (132/266, 49\%), Marinobacter aquaeolei VT8 (128/267, 47\%), Rhodospirillum rubrum ATCC 11170 (130/263, 49\%) and Nitrosococcus oceani ATCC 19707 $(124 / 270,45 \%)$. Multiple alignments of the deduced amino acids of Pye with the most homologous proteins were presented in Figure 1. The putative protein contained the conserved active site motif of the pentapeptide GxSxG found in most bacterial and eucaryotic serine hydrolases (residues from 141 to 146 )with a serine acting as the catalytic nucleophile, a conserved aspartate or glutamate and a histidine, together constituting a catalytic triad sequence (Ser 143, Asp214, His 251) [19,20]. An unrooted phylogenetic tree based on the amino acid sequences was constructed in order to further verify the evolutionary relationship of the Pye 3 protein to other known lipase/ esterase proteins, and 24 bacterial lipase/esterase proteins representing 8 different families were selected for the phylogenetic tree analysis [21]. As shown in Figure 2, the Pye3 protein belongs to Family I.

\section{Overexpression and purification of recombinant Pye3}

To investigate the biochemical property of Pye3, the cloned gene was subcloned in frame with a six-histidine tag sequence into a T7 RNA polymerase derived E. coli expression vector of pET 32a + (Novagen) and expressed in E. coli BL21 (DE3) with $0.5 \mathrm{mM}$ IPTG induction. The recombinant Pye3 was purified by Ni-NTA chromatography. Taking into consideration that the resulting recombinant protein should consist of the 272 amino acids with an N-terminal fusion of 156 amino acids corresponding to thioredoxin tag (Trx-tag), polyhistidine tag (His-tag), S. tag epitope (S. tag) and a unique thrombin cleavage site (Thrombin), and its total molecular mass should be about $48 \mathrm{kDa}$. It was observed about $48 \mathrm{kDa}$ in a Coomassiestained SDS-PAGE (Fig. 3). This result is in agreement with the calculated molecular mass of the predicted amino acid sequence $(31,15 \mathrm{kDa})$. The relative molecular mass of native enzyme estimated by gel filtration on a calibrated column of Sephacryl $200 \mathrm{HR}$ was 73,000 Da. Hence, it is assumed that the purified enzyme (Pye 3 ) is a monomer. The pI value was estimated to be 5.2.

\section{The effect of $\mathrm{pH}$ and temperature on catalytic activity and stability}

With $\rho$-nitrophenyl acetate as a substrate, the $\mathrm{pH}$ ranged from 3.5 to 10.0 and the temperature ranged from 20 to $70^{\circ} \mathrm{C}$. The absorption of $\rho$-nitrophenol varies when $\mathrm{pH}$ is altered because of changes in equilibrium between $\rho$ nitrophenol and $\rho$-nitrophenoxide. Therefore, the release of $\rho$-nitrophenol was monitored at $384 \mathrm{~nm}$. The $\mathrm{pH}$-activity profile of the enzyme was bell-shaped, with maximum values at $\mathrm{pH}$ 7.0. The enzyme was found to be stable in the $\mathrm{pH}$ range of 5.5 to 9.0 . The optimal temperature for the enzyme was $40^{\circ} \mathrm{C}$. The enzyme was fairly stable at up to $45^{\circ} \mathrm{C}$ and had $54 \%$ of its activity at $50^{\circ} \mathrm{C}$. It was completely inactivated at $65^{\circ} \mathrm{C}$.

The effects of reagents and metal ions on enzyme activity The presence of $\mathrm{Hg}^{2+}$ and $\mathrm{Ag}^{+}$caused a complete inhibition at $0.5 \mathrm{mM}$, while less pronounced effect was observed in the presence of the divalent cations $(0.5 \mathrm{mM})$. The enzyme activity was strongly inhibited by $0.1 \mathrm{mM} \rho$-chloromercuribenzoate, whereas the chelating agent EDTA and phenanthroline $(1 \mathrm{mM})$ showed little effect on the enzymatic activity. 


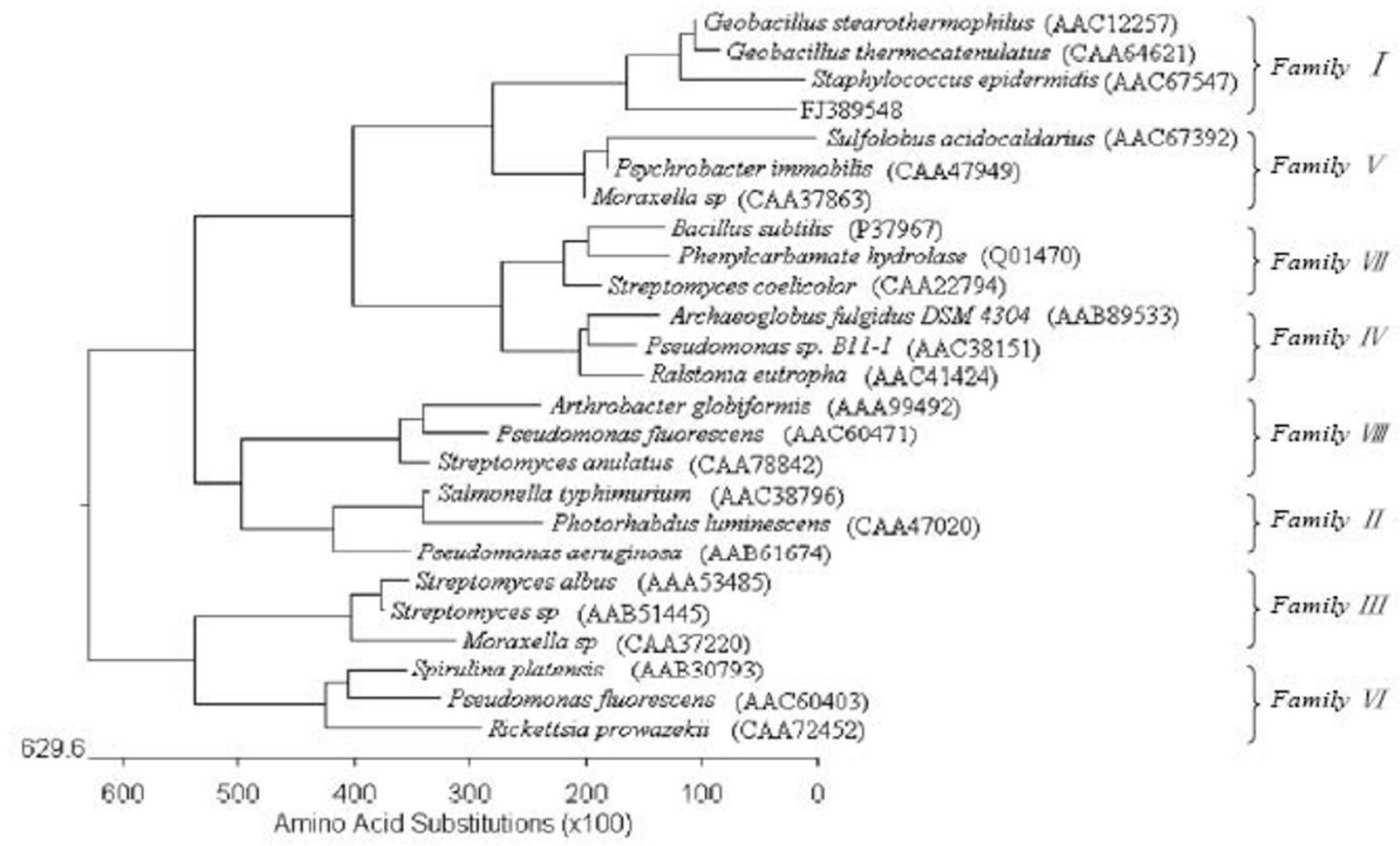

Figure 2

Phylogenetic relationship of Pye3 and lipase/esterase proteins of 8 different families was performed using the program MEGALIGN (DNASTAR, Madison, WI). Except for Pye3, the other protein sequences for previously identified families of bacterial lipolytic and esterolytic enzymes were retrieved from GenBank under following accession numbers: our metagenome (FJ389548), Pseudomonas fluorescens (AAC60403), Spirulina platensis (AAB30793), Rickettsia prowazekii (CAA72452), Arthrobacter oxydans (Q01470), Bacillus subtilis (P37967), Streptomyces coelicolor (CAA22794), Archaeoglobus fulgidus DSM 4304 (AAB89533), Pseudomonas sp. BI I - I (AAC38I5I), Ralstonia eutropha (AAC4I424), Pseudomonas fluorescens (AAC60471), Streptomyces anulatus (CAA78842), Arthrobacter globiformis (AAA99492), Salmonella typhimurium (AAC38796), Photorhabdus luminescens (CAA47020), Pseudomonas aeruginosa (AAB61674),Moraxella sp. (CAA37220), Streptomyces albus (AAA53485), Streptomyces sp. (AAB5|445), Geobacillus stearothermophilus (AACI2257), Geobacillus thermocatenulatus (CAA6462I), Staphylococcus epidermidis (AAC67547), Moraxella sp. (CAA37863), Psychrobacter immobilis (AA47949), Sulfolobus acidocaldarius (AAC67392). The units at the bottom of the tree indicate the number of substitution events.

\section{Substrate specificity}

The substrate specificity towards $\rho$-nitrophenyl esters of various fatty acids was shown in Table 1 . Pye 3 showed the highest activity with $\rho$-nitrophenyl caproate $(426 \mathrm{U} / \mathrm{mg}$ ) among the $\rho$-nitrophenyl esters examined. Both $K_{\mathrm{m}}$ and $k_{\text {cat }}$ values of purified Pye 3 decreased with increases in aliphatic chain length up to $\mathrm{C}_{4}$. The comparison of catalytic efficiency values $\left(k_{\mathrm{cat}} / K_{\mathrm{m}}\right)$ for various substrates indicated that these values were dependent on the aliphatic chain length of substrate. Short-chain $\rho$-nitrophenyl esters seemed to be preferred substrates, whereas $\rho$-nitrophenyl esters of longer-chain fatty acids were poor substrates, Pye3 had no activity against $\rho$-nitrophenyl myristate and $\rho$-nitrophenyl palmitate. Activity to $\rho$-nitrophenyl esters of shorter-chain fatty acids was lower than that of $\rho$-nitrophenyl butyrate. Taking into consideration that lipases prefer substrates with relatively long aliphatic chains, these results showed the purified enzyme (Pye3) is an esterase and not a lipase.

A range of pesticides such as organophosphorus insecticide malathion whose structures are similar to pyrethroid, cis-permethrin, trans-permethrin, cypermethrin, fenvalerate, and deltamethrin were tested for substrate specificity of the recombinant Pye3. The Pye3 hydrolyzed the pesticides tested at different hydrolysis rate (Table 2), the transpermethrin was hydrolyzed most rapidly, while deltamethrin was the least readily attacked, cis-permethrin was 


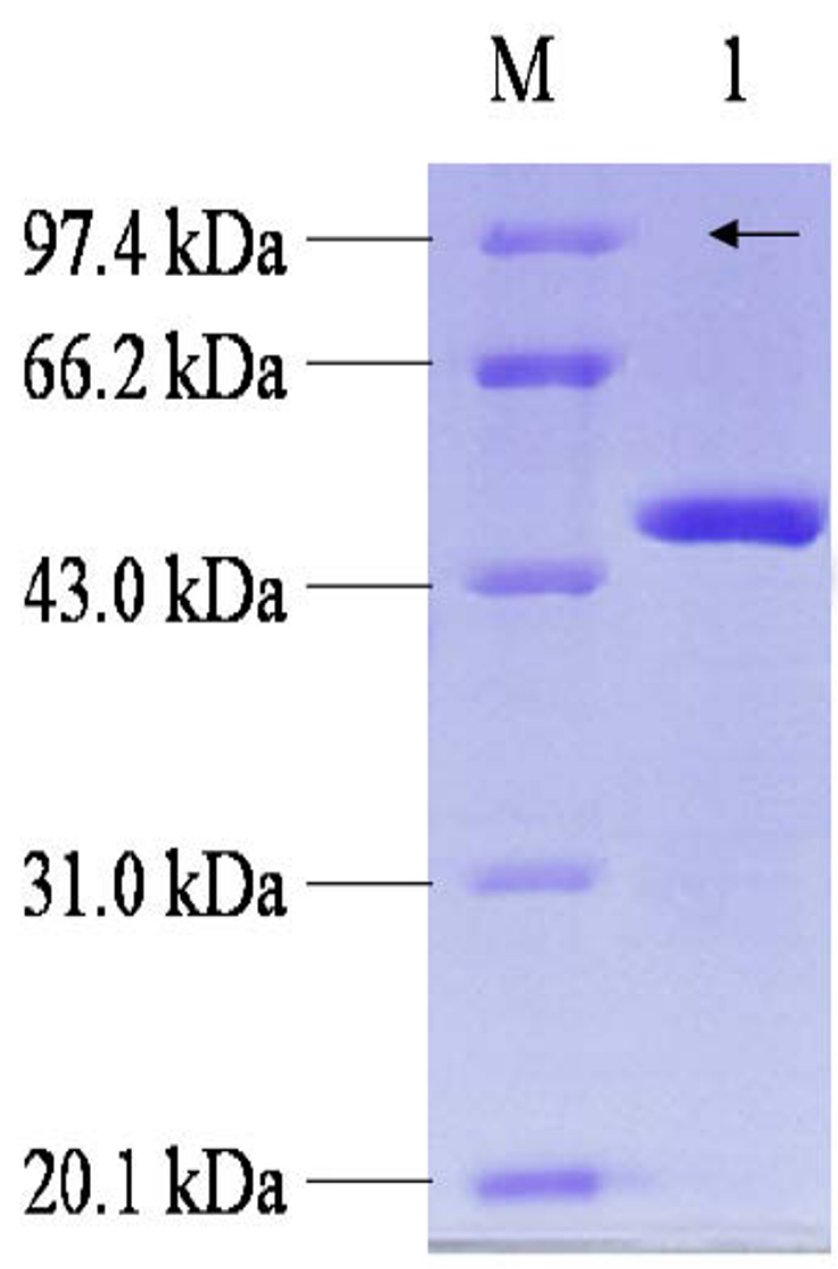

Figure 3

SDS-PAGE analysis of the purified $\mathrm{His}_{6}$-tagged mature Pye3. Arrowhead indicates target protein (lane I), protein markers (lane M) stained with Coomassie blue. Markers from top to bottom are phosphorylase b $(97.4 \mathrm{kDa})$, bovine serum albumin (66.2 kDa), ovalbumin (43 kDa), carbonic anhydrase $(3 \mathrm{l} \mathrm{kDa})$ and trypsin inhibitor $(20.1 \mathrm{kDa})$.

hydrolyzed approximately equal rate toward trans-permethrin. The $K_{\mathrm{m}}$ and $k_{\text {cat }}$ values were calculated by fitting the data to Michaelis-Menten equation (Table 2). The purified enzyme showed comparable affinity against a range of structurally similar pesticides with $K_{\mathrm{m}}$ values ranging $0.1-1.41 \mu \mathrm{M}$.

\section{Discussion}

Soil is often considered to be one of the main reservoirs of microbial diversity on the planet [22]. However, the inability to cultivate most soil bacteria hampered fundamental attempts to determine the diversity of the prokaryotic world and limited its industrial exploitation. In the last 20 years, new methods have been developed to overcome these limitations based on the direct extraction of DNA from bacteria in their natural environment. Metagenomic approaches promise the accessibility of the genetic resources and their potential biotechnological applications [13,23-25].

In fact, like most other proteins screened from metagenomic libraries, no information about a source microorganism could be obtained. Therefore, the success rate (the number of positives divided by the library size) is relatively low $[17,26]$. In this study, the metagenomic library represented about $390 \mathrm{Mb}$ of soil microbial community DNA was constructed. Through screening 93,000 clones, 6 esterase-positive transformants displayed blue color in LB containing X-caprylate. Of which only one positive clone among them was able to hydrolyze pyrethroid by pyrethroid-hydrolyzing experiment. This confirms the general trend that the discovery of novel pyrethroidhydrolyzing enzyme from the metagenome is not straightforward. The reason for low yield of novel pyrethroidhydrolyzing esterases can be attributed to a number of different factors, including the library construction (source of DNA, number of clones, and average insert size of metagenomic DNA), the probable unrecognition of regulatory elements from unknown bacteria in E. coli, difficulties of expression in heterologous host, the formation of inclusion bodies, toxicity of expressed protein to host, sufficient quantities and stability of genes encoding proteins and the choice of host organism. Therefore, this suggests that the discovery of specific genes in a complex metagenome is technically challenging.

Fortunately, metagenomic libraries were constructed by using the vector pZErO-2, and a novel pyrethroid-hydrolyzing esterase gene was thus isolated and characterized. Taking into consideration the complexity in the course of directly cloning of pyrethroid-hydrolyzing esterase gene, the ability to produce a blue precipitate pertinent to esterase enables screening for novel esterases from metagenomic libraries using $E$. coli as a host organism. In this study, we initially selected 6 blue color transformants with the esterase activity in LB agar plates containing 100 $\mu \mathrm{M}$ X-caprylate, the ability of those blue transformants with the esterase activity to hydrolyze permethrin was subsequently demonstrated by assaying permethrin reduction, and further analysis determined that only one transformant with the esterase activity hydrolyzed permethrin. These results showed that not all esterases are capable of degrading pyrethroids. Furthermore, the Pye 3 not only efficiently hydrolyzed $\rho$-nitrophenyl esters of medium-short chain fatty acids, but also degraded pyrethroid pesticides tested, indicating that the Pye 3 is an esterase with broader specificity. Although there have been some reports on pyrethroid hydrolase from pyrethroidresistant insects, mammal organ, Aspergillus niger and 
Bacillus cereus $[1,3,9,27]$, some nucleotide sequences of the pyrethroid-hydrolyzing enzyme genes were available (accession no. NM-133960, accession no. NM-144930, accession no. AY487948, accession no. Q964Q7, accession no. Q27698) $[28,29]$, the pyrethroid pesticide degradative gene from the metagenomic library has not been previously reported. To our knowledge, this is the first one to be determined for pyrethroid-hydrolyzing enzyme gene from the metagenomic library constructed from vegetable soil.

The gene (pye) was cloned and expressed in Escherichia coli BL21 (DE3), and its product was purified to apparent homogeneity and characterized. As a monomeric 31.15 $\mathrm{kDa}$ protein, the molecular mass of the Pye 3 is smaller than those of the purified permethrinase $(61,000 \mathrm{Da})$ from bacteria, the pyrethroid hydrolase $(56,000 \mathrm{Da})$ from Aspergillus niger ZD11, pyrethroid-hydrolyzing carboxylesterase (60,000 Da) from mouse liver microsomes, and carboxylesterase E3 $(58,600 \mathrm{Da})$ from Nephotettix cincticeps Uhler. The $\mathrm{pH}$ optimum of the Pye3 (pH 7.0) was lower than that recorded from Bacillus cereus (pH 7.5) and higher than that reported from Aspergillus niger ZD11 ( $\mathrm{pH}$ 6.5). The optimal temperature of $40^{\circ} \mathrm{C}$ is similar to that recorded from Bacillus cereus $\left(37^{\circ} \mathrm{C}\right)$ and lower that reported from Aspergillus niger ZD11 $\left(45^{\circ} \mathrm{C}\right)[3,9]$.

The substrate specificity on different substrates was studied with the purified recombinant enzyme. The striking feature for $\rho$-nitrophenyl caproate and $\rho$-nitrophenyl caprylate was quite different from the specificities of other microbial esterases [30], which are mainly specific for $\rho$ nitrophenyl esters of short-chain fatty acids, only the enzymes from Bacillus. stearothermophilus [31], Sulfolobus acidocaldarius [32], Bacillus licheniformis [33], and Lactobacillus casei CL96 [34] showed specificity patterns are similar to that of Pye3. Since the purified recombinant enzyme hydrolyzed cypermethrin, permethrin, fenvalerate, deltamethrin, and malathion. Therefore, pyrethroid-hydrolyzing esterase seems to be capable of hydrolyzing a relatively wide range of compounds with similar chemical linkage, suggesting that it possessed broader substrate specificities, and this feature is same as pyrethroid hydrolase from Aspergillus niger ZD11 [3]. However, this observation does not quite agree with data reported by Motoyama et al. and Stok et al. [27]. The pyrethroid-hydrolyzing carboxylesterase (BAC36707) from mouse liver microsomes did not hydrolyze malathion. On the other hand, Motoyama et al. found that one of five forms of carboxylesterases degraded malathion twice as fast as the fenvalerate, and three other forms possessed approximately equal activity toward these two insecticides. In a previous paper, there was a preference in both mammals and insects carboxylesterases for permethrin to cypermethrin, and transpermethrin to cis-permethrin $[8,27]$, while carboxylesterase from Nephotettix cincticeps Uhler prefered cis-permeth- rin to trans-permethrin. But the pyrethroid-hydrolyzing esterase possessed approximately equal activity toward permethrin isomers. Therefore, it lacked stereoselectivity, and this feature is different from that of carboxylesterase E3 from Nephotettix cincticeps Uhler [8] and carboxylesterase (BAC36707) [27]. In addition, the apparent $K_{\mathrm{m}}$ values obtained for the purified enzyme (Pye3) were lower than those for pyrethroid-hydrolyzing carboxylesterase (BAC36707) from mouse liver microsomes, carboxylesterase E3 from Nephotettix cincticeps Uhler and pyrethroid hydrolase from Aspergillus niger ZD11 when the same substrates were used, indicating a higher affinity for these substrates in the case of the Pye3. The comparison of $K_{\mathrm{m}}$ and $k_{\text {cat }}$ revealed that he pyrethroid-hydrolyzing esterase has about 14-fold higher affinity towards trans-permethrin than deltamethrin and can hydrolyze the former about 173-fold faster than the latter. The catalytic efficiencies $\left(k_{\mathrm{cat}} / K_{\mathrm{m}}\right)$ are considered as a measurement of the enzyme,s specificity, among these substrates indicate that trans-permethrin is clearly the preferred substrate.

\section{Conclusion}

In summary, the pyrethroid-hydrolyzing esterase gene was successfully cloned using metagenomic DNA combined with activity-based functional screening from soil, the recombinant Pye has been purified and characterized. Taking into consideration that pesticidal residues resulting from agricultural production are complex mixtures, enzymatic bioremediation requiring the development of specific enzymes for each compound or isomer is unrealistic, therefore, the broader substrate specificities and higher activity of the pyrethroid-hydrolyzing esterase were necessary to fulfill the practical requirements of bioremediation to enable its use in situ for detoxification of pyrethroids where they cause environmental contamination problems. Further studies will supply important data for future application of novel pyrethroid-hydrolyzing esterase for promising environmental protection.

\section{Methods \\ Chemicals and Reagents}

Cypermethrin (98\%), trans-Permethrin and cis-Permethrin (99\%), Fenvalerate (98\%), malathion (98\%), and Deltamethrin $(98 \%)$ were kindly provided by Zhong shan Pesticide Factory (Guang dong, China). All $\rho$-nitrophenyl esters were purchased from Sigma. All other chemicals and reagents were of analytical grade and were purchased from commercial sources, unless otherwise stated.

\section{Strains, media, and plasmids}

E. coli TOP10 was used as a host for recombinant plasmids. The pET-32a (+) (Novagen) was used as an overexpression vector to produce the target protein.E. coli BL21 (DE3) was used as a host for expression of the pye3 gene under the control of the T7 promoter. E. coli transformants were grown at $37^{\circ} \mathrm{C}$ in Luria-Bertani (LB) broth con- 
taining, when necessary, the LB medium was supplemented $50 \mu \mathrm{g} / \mathrm{mL}$ kanamycin, unless otherwise stated.

\section{DNA manipulation}

Routine DNA manipulations were carried out according to standard techniques. Restriction enzymes and DNA polymerase were purchased from Takara (Dalian, China). Each enzyme was used according to the recommendations of the manufacturer. DNA ligations were performed using T4 DNA ligase (Fermentas). Plasmids were prepared from E. coli by using a QIAGEN miniplasmid purification kit according to the manufacturer's instructions (QIAGEN Inc.). DNA fragments were isolated from agarose gels by using a QIAquick gel extraction kit (QIAGEN Inc.). The E. coli TOP10 and vector pZErO-2 were purchased from Invitrogen (Invitrogen, USA). Electroporation was performed with a Gene-Pulser II electroporation apparatus (Bio-Rad Laboratories).

\section{Sequencing and analysis of pyrethroid-hydrolyzing esterase gene}

Sequencing reactions were performed using a BigDye sequencing kit according to the instructions of the manufacturer. DNA sequencing of positive plasmid clone (pZP6-3) was analyzed on ABI 377 DNA sequencer. Sequence manipulation, open reading frame (ORF) searches, and multiple alignments among similar enzymes were conducted with DNASTAR software. Database homology search was performed with BLAST program provided by NCBI. The conserved patterns of discrete amino acid sequences related enzymes were analyzed by Clustal W program.

\section{DNA extraction from soil samples}

The topsoil samples ( 5 to $10 \mathrm{~cm}$ ) from vegetable soil were used for the experiments. Samples were collected and stored at $-80^{\circ} \mathrm{C}$ until the DNA extraction was performed. Extraction of the total genomic DNA from vegetable soil was performed using with the Fast DNA ${ }^{\circledR}$ SPIN kit for soil according to the recommendations of suppliers (MP Biomedicals, USA).

\section{Construction of genomic libraries and screening for pyrethroid-hydrolyzing esterase gene}

The metagenomic library was constructed from environmental DNA isolated from vegetable soil using protocols provided by the manufacturer. DNA fragments ( 3 to $8 \mathrm{~kb}$ ) obtained after partial Sau3AI digestion were ligated into the BamHI restriction site of the pZErO-2 vector, which had been previously digested with BamHI. E. coli TOP10 was transformed by electroporation with the library and plated onto Luria-Bertani (LB) agar plates containing 50 $\mu \mathrm{g} / \mathrm{mL}$ kanamycin, $100 \mu \mathrm{M}$ 5-bromo-4-chloro-3-indolylcaprylate (X-caprylate) and $0.5 \mathrm{mM}$ isopropyl- $\beta$-D-thioga- lactopyranoside (IPTG). A total of approximate 93,000 transformants were generated. A functional esterase screening was visualized performed by blue color, which was resulted from the hydrolysis of X-caprylate. To avoid the isolation of false-positive clones, plasmid DNA was isolated from the positive clones obtained in the initial screening and retransformed, and the new clones were examined on the same type of indicator plates for esterase activity. The 6 blue colonies were further tested for its ability to hydrolyze permethrin through (GC-MS) analyses [3]. The only one transformant with pyrethroid-hydrolyzing esterase was obtained and confirmed. Subsequently, the plasmid was subjected to restriction analysis with BamHI to identify the uniqueness of the clone. Unique clones were sequenced to identify the inserted fragment of metagenomic DNA. The fragment size of the plasmids was $6.3 \mathrm{~kb}$. The size of the insert DNA fragment of the plasmid pZP6 was reduced by using the EcoRI restriction site. The resulting DNA fragment of $2.6 \mathrm{~kb}$ from plasmid pZP6 was ligated into a EcoRI -digested pZErO-2 plasmid. The ligated DNA was introduced into E. coli TOP10, the resulting clone Escherichia coli TOP10 (pZP6-3) was tested for its ability to hydrolyze permethrin through (GC-MS) analyses [3].

\section{Cloning and over-expression and purification of pyrethroid-hydrolyzing esterase}

The putative esterase gene was amplified from the pZP6-3 plasmid by using the primers and to introduce Bam HI and HindIII restriction sites for cloning in the pET32a (+). The following primers were used: pye-fw (5-CGCGGATCCATGCCAAGTGATCAAAGAG; the BamHI site is shown in italics) and pye-rv (5-CCCAAGCTTGTTGGTGTCCTGCAGGAAAC; the HindIII site is shown in italics). The PCR product was digested with $\mathrm{BamHI} / \mathrm{HindIII}$, and then ligated into BamHI/HindIII digested expression vector pET-32a (+), and transformed into E. coli BL21 (DE3) (Stratagene). The E. coli transformed with this plasmid was plated on LB agar containing $50 \mu \mathrm{g} / \mathrm{mL}$ kanamycin. The transformant was grown in a $250-\mathrm{ml}$ flask containing $50 \mathrm{ml} \mathrm{LB}$ medium supplemented with $50 \mu \mathrm{g} / \mathrm{mL}$ kanamycin at $37^{\circ} \mathrm{C}$ until the cell concentration reached $\mathrm{OD}_{600} \mathrm{~nm}$ of 0.6 , and $0.1 \mathrm{mM}$ isopropyl- $\beta$-D-thiogalactopyranoside (IPTG) of a final concentration to induce target protein expression. After incubation at $25^{\circ} \mathrm{C}$ for $18 \mathrm{~h}$ with shaking at $200 \mathrm{rpm}$, Cells were harvested by centrifugation $(6$, $000 \mathrm{~g}$ for $20 \mathrm{~min}$ at $4^{\circ} \mathrm{C}$ ) and resuspended in $50 \mathrm{mM}$ Tris$\mathrm{HCl}$ (pH 7.6)-10 mM EDTA and disrupted by sonication for $10 \mathrm{~s}$ in ice-water bath. The cell debris was removed by centrifugation at $10,000 \mathrm{~g}$ for $5 \mathrm{~min}$ at $4^{\circ} \mathrm{C}$. The clear supernatant was collected and the recombinant Pye was purified with his-tag affinity column. The supernatant was applied to a Ni-nitrilotriacetic acid (Ni-NTA) affinity chromatography column (Qiagen, Hilden, Germany), equilibrated with buffer A (10 mM Tris- $\mathrm{HCl}, 500 \mathrm{mM} \mathrm{NaCl}, 5$ 
$\mathrm{mM}$ imidazole, $\mathrm{pH} 8$ ) at a flow rate of $0.5 \mathrm{~mL} / \mathrm{min})$. The bound protein was eluted with buffer B $(10 \mathrm{mM}$ Tris- $\mathrm{HCl}$, $500 \mathrm{mM} \mathrm{NaCl}, 500 \mathrm{mM}$ imidazole, $\mathrm{pH} \mathrm{8}$ ) at $4^{\circ} \mathrm{C}$. The purity of the enzyme was estimated by SDS (sodium dodecyl sulfate)-PAGE (polyacrylamide gel electrophoresis) in the eluted fractions, using $12 \%$ polyacrylamide running gels. Protein concentration was determined by the method of Bradford, bovine serum albumin (Sigma) was used as standard for calibration [35]. Enzyme samples were stored at $-20^{\circ} \mathrm{C}$ until further use.

\section{Determination of molecular mass and isoelectric point}

The molecular mass of the denatured protein was determined by sodium dodecyl sulfate-polyacrylamide gel electrophoresis (SDS-PAGE). 12\% SDS-PAGE was prepared by the method of Laemmli [36]. Proteins were stained with Coomassie brilliant blue G. The molecular mass of the enzyme subunit was estimated using protein marker as standards. The molecular mass of the native protein by gel filtration on a Superose 12HR 5/30 column, gamma globulin $(160,000 \mathrm{Da})$, bovine serum albumin $(67,000$ Da), ovalbumin $(43,000 \mathrm{Da})$, carbonic anhydrase (30, $000 \mathrm{Da})$, was used as the reference proteins. Isoelectric point (pI) was estimated by PAGE with 6.25\% Ampholine ( $\mathrm{pH} 3.5 \sim 10)$ in a gel rod $(0.5$ by $10 \mathrm{~cm})$ using a kit for Isoelecric Focusing Calibration according to recommendations by the supplier.

\section{Analysis of enzyme activity}

The esterase activity against $\rho$-nitrophenyl esters was determined by measuring the amount of $\rho$-nitrophenol released by esterase-catalyzed hydrolysis. The hydrolysis of substrate was performed at $30^{\circ} \mathrm{C}$ for $10 \mathrm{~min}$ in $50 \mathrm{mM}$ sodium phosphate buffer ( $\mathrm{pH} 7.0$ ) containing $1 \%$ acetonitrile. The production of $\rho$-nitrophenol was monitored at $405 \mathrm{~nm}$ by Labsystems Dragon Wellscan MK3. One unit of enzyme activity was defined as the amount of enzyme that produced $1 \mu \mathrm{mol}$ of $\rho$-nitrophenol per minute from substrate under these conditions $[3,17,37]$. The pyrethroid-hydrolyzing esterase activities against pesticides and the pesticide assay were performed as described by Liang et al. [3].

The optimum $\mathrm{pH}$ of the pyrethroid-hydrolyzing esterase was measured using $\rho$-nitrophenyl caproate as a substrate at $30^{\circ} \mathrm{C}$. The buffers (at a final concentration of $50 \mathrm{mM}$ ) used for the measurement were as below: citric acid$\mathrm{NaOH}$ (pH 3.5 to 5.5); potassium phosphate (pH 5.0 to 7.0); Tris-HCl buffer ( $\mathrm{pH} 6.5$ to 9.0), glycine-NaOH buffer ( $\mathrm{pH} 8.5$ to 10.0). Overlapping $\mathrm{pH}$ values were used to verify that there were no buffer effects on substrate hydrolysis. The optimum temperature was determined analogously by measuring esterase activity at $\mathrm{pH} 7.0$ in the temperature range of $20-70^{\circ} \mathrm{C}$. The $\mathrm{pH}$ stability was tested after incubation of the purified enzyme for $2 \mathrm{~h}$ at $30^{\circ} \mathrm{C}$ in the above different buffers. Temperature stability was measured after incubation of the purified enzyme in $50 \mathrm{mM}$ sodium phosphate buffer ( $\mathrm{pH} 7.0$ ) for $1 \mathrm{~h}$ at different temperature $[17,38]$. The effects of various chemicals $\left(\mathrm{CaCl}_{2}, \mathrm{MgSO}_{4}, \mathrm{CuSO}_{4}, \mathrm{ZnSO}_{4}, \mathrm{MnCl}_{2}, \mathrm{AgNO}_{3}\right.$, $\mathrm{HgCl}_{2}$, EDTA, phenanthroline, $\rho$-chloromercuribenzoate) on the pyrethroid-hydrolyzing esterase activity were investigated by addition of the tested compounds into the reaction mixture, which was preincubated for $30 \mathrm{~min}$ at $30^{\circ} \mathrm{C}$. The activity was then measured described above and expressed as a percentage of the activity obtained in the absence of the added compound. Taking into consideration the fact that the poor solubility of most metal ions in phosphate buffer, we use $50 \mathrm{mM} \mathrm{N}$ - (2-hydroxyethyl)piperazine-N'- (2-ethanesulfonic acid)-NaOH buffer (pH 7.0) in place of $50 \mathrm{mM}$ sodium phosphate buffer.

\section{Determination of kinetic parameters}

Kinetic parameters against $\rho$-nitrophenyl esters were determined by measuring enzyme activity using $\rho$-nitrophenyl acetate ranging from 0.02 to $1.5 \mathrm{mM}, \rho$-nitrophenyl propionate ranging from 0.01 to $0.8 \mathrm{mM}, \rho$ nitrophenyl butyrate ranging from 0.008 to $0.5 \mathrm{mM}, \rho$ nitrophenyl caproate ranging from 0.003 to $0.2 \mathrm{mM}, \rho$ nitrophenyl caprylate ranging from 0.005 to $0.4 \mathrm{mM}, \rho$ nitrophenyl laurate and $\rho$-nitrophenyl myristate ranging from 0.03 to $2 \mathrm{mM}$ as a substrates in $50 \mathrm{mM}$ sodium phosphate buffer ( $\mathrm{pH} 7.0$ ) containing $1 \%$ acetonitrile at $30^{\circ} \mathrm{C}$. An additional $0.04 \%$ Triton $\mathrm{X}-100$ was included in the reaction mixture in the case $\rho$-nitrophenyl caprylate. With $\rho$-nitrophenyl palmitate as a substrate, 4\% 2-propanol was included in the reaction mixture in order to solubilize the substrate. Kinetic parameters against different pesticides were analogously determined by measuring enzyme activity over a range of final concentrations from 0.005 to $7 \mu \mathrm{M}$ dependent on different pesticides. All initial velocities were determined at 5 time points which no more than $10 \%$ of the substrate had been consumed, and solution content never exceeded $1 \%$ of the total assay volume, so the decrease in substrate concentration remains linear with time over the period of measurement and the rate was almost constant throughout the assay, r-square values ranged from 0.963-0.971 according to different substrates. Initial reaction velocities measured at various concentrations of substrates were fitted to the LineweaverBurk transformation of Michaelis-Menten equation [39]. Kinetic analyses by curve fitting were performed with the SigmaPlot software [3].

\section{Nucleotide sequence accession number}

The nucleotide sequence data reported here have been submitted to the nucleotide sequence databases under accession number (FJ389548).

\section{Competing interests}

The authors declare that they have no competing interests. 


\section{Authors' contributions}

GL: he carried out gene cloning, expression and characterization of protein together with KW. KW: he constructed metagenomic library from soil, carried out the bioassay of enzyme activity and analyzed data. YHL: he conceived the study, designed and supervised the experiments, and drafted and revised the manuscript. All authors have read and approved the manuscript.

\section{Acknowledgements}

We are grateful to National Natural Science Foundation of China (30570055), the National High Technology Research and Development Program of China (863 Program) (2007AA 10Z308), and the Science and Technology Plan Project of Guangdong province (2007A0 1090000I) for their financial support.

\section{References}

I. Heidari R, Devonshire AL, Campbell BE, Dorrian SJ, Oakeshott JG, Russell RJ: Hydrolysis of pyrethroids by carboxylesterases from Lucilia cuprina and Drosophila melanogaster with active sites modified by in vitro mutagenesis. Insect Biochem Mol Biol 2005, 35:597-609.

2. Lee SJ, Gan JY, Kabashima J: Recovery of synthetic pyrethroids in water samples during storage and extraction. J Agric Food Chem 2002, 50:7194-7198.

3. Liang WQ, Wang ZY, Li H, Wu PC, Hu JM, Luo N, Cao LX, Liu YH: Purification and characterization of a novel pyrethroid hydrolase from Aspergillus niger ZDI I. J Agric Food Chem 2005, 53:7415-7420.

4. Park EK, Kim JH, Gee SJ, Watanabe T, Hammock BD: Determination of pyrethroid residues in agricultural products by an enzyme-linked immunosorbent assay. J Agric Food Chem 2004, 52:5572-6.

5. Shan GM, Huang HZ, Stoutamire DW, Gee SJ, Leng G, Hammock BD: A sensitive class specific immunoassay for the detection of pyrethroid metabolites in human urine. Chem Res Toxicol 2004, I 7:2 18-225

6. Lutnicka H, Bogacka T, Wolska L: Degradation of pyrethroids in an aquatic ecosystem model. Wat Res 1999, 33:344I-3446.

7. Crow JA, Borazjani A, Potter PM, Ross MK: Hydrolysis of pyrethroids by human and rat tissues: examination of intestinal, liver and serum carboxylesterases. Toxicol Appl Pharmacol 2007, $221: 1-12$.

8. Chiang SW, Sun CN: Purification and characterization of carboxylesterases of a rice green leafhopper Nephotettix cincticeps uhler. Pestic Biochem Physiol 1996, 54:181-189.

9. Maloney SE, Maule A, Smith AR: Purification and preliminary characterization of permethrinase from a pyrethroid-transforming strain of Bacillus cereus. Appl Environ Microbiol 1993, 59:2007-2013

10. Grant RJ, Daniell TJ, Betts WB: Isolation and identification of synthetic pyrethroid-degrading bacteria. J Appl Microbiol 2002, 92:534-540.

I I. Lee SJ, Gan JY, Kim JS, Kabashima JN, Crowley DE: Microbial transformation of pyrethroid insecticides in aqueous and sediment phases. Environ Toxicol Chem 2004, 23: I-6.

12. Lorenz P, Eck J: Metagenomics and industrial applications. Nat Rev Microbiol 2005, 3:510-5I6.

13. Wilmes $\mathrm{P}$, Bond PL: Metaproteomics: studying functional gene expression in microbial Ecosystems. Trends Biotechnol 2006, 14:92-97.

14. Cowan D, Meyer Q, Stafford W, Muyanga S, Cameron R, Wittwer P: Metagenomic gene discovery: past, present and future. Trends Biotechnol 2005, 23:321-329.

15. Kim YJ, Choi GS, Kim SB, Yoon GS, Kim YS, Ryu YW: Screening and characterization of a novel esterase from a metagenomic library. Protein Expr Purif 2005, 45:315-323.

16. Ranjan R, Grover A, Kapardar RK, Sharma R: Isolation of novel lipolytic genes from uncultured bacteria of pond water. Biochem Biophys Res Commun 2005, 335:57-65.
17. Rhee JK, Ahn DG, Kim YG, Oh JW: New thermophilic and thermostable esterase with sequence similarity to the hormonesensitive lipase family, cloned from a metagenomic library. Appl Environ Microbiol 2005, 71 :8I 7-825.

18. Ferrer M, Golyshina OV, Chernikova TN, Khachane AN, Martins dos Santos VA, Yakimov MM, Timmis KN, Golyshin PN: Microbial enzymes mined from the Urania deep-sea hypersaline anoxic basin. Chem Biol 2005, I 2:895-904.

19. Bornscheuer UT: Microbial carboxyl esterases: classification, properties and application in biocatalysis. FEMS Microbiol Rev 2002, 26:73-8I.

20. Wei Y, Schottel JL, Derewenda U, Swenson L, Patkar S, Derewenda ZS: A novel variant of the catalytic triad in the Streptomyces scabies esterase. Nat Struct Biol 1995, 2:218-223.

21. Lee $\mathrm{MH}$, Lee $\mathrm{CH}$, Oh TK, Song JK, Yoon JH: Isolation and characterization of a novel lipase from a metagenomic library of tidal flat sediments: evidence for a new family of bacterial lipases. Appl Environ Microbiol 2006, 72:7406-7409.

22. Jiang C, Wu B: Molecular cloning and functional characterization of a novel decarboxylase from uncultured microorganisms. Biochem Biophys Res Commun 2007, 357:421-426.

23. Tirawongsaroj P, Sriprang R, Harnpicharnchai P, Thongaram T, Champreda V, Tanapongpipat S, Pootanakit K, Eurwilaichitr L: Novel thermophilic and thermostable lipolytic enzymes from a Thailand hot spring metagenomic library. J Biotechnol 2008, I 33:42-49.

24. Lämmle K, Zipper H, Breuer M, Hauer B, Buta C, Brunner H, Rupp S: Identification of novel enzymes with different hydrolytic activities by metagenome expression cloning. J Biotechnol 2007, I 27:575-592.

25. Lee CM, Yeo YS, Lee JH, Kim SJ, Kim JB, Han NS, Koo BS, Yoon SH: Identification of a novel 4-hydroxyphenylpyruvate dioxygenase from the soil metagenome. Biochem Biophys Res Commun 2008, 370:322-326.

26. Hårdeman F, Sjöling S: Metagenomic approach for the isolation of a novel low-temperature-active lipase from uncultured bacteria of marine sediment. FEMS Microbiol Ecol 2007, 59:524-534.

27. Stok JE, Huang HZ, Jones PD, Wheelock CE, Morisseau C, Hammock $B D$ : Identification, expression, and purification of a pyrethroid-hydrolyzing carboxylesterase from mouse liver microsomes. J Biol Chem 2004, 279:29863-29869.

28. Feyereisen RJ, Koener JF, Farnsworth DE: Isolation one sequence of cDNA encoding a cytochrome P450 from an insecticideresistant strain of the house fly, Musca domestica. Proc Nat Acad Sci USA 1989, 86:|465-|472.

29. Kasai S, Shono T: Molecular cloning and nucleotide sequence of a cytochrome P450 cDNA from a pyrethroid-resistant mosquito Culex quinquefasciatus. Insect Mol Biol 1998, 7:185-190.

30. Riou C, Salmon JM, Vallier MJ, Günata Z, Barre P: Purification, characterization, and substrate specificity of a novel highly glucose-tolerant $\beta$-glucosidase from Aspergillus oryza. Appl Environ Microbiol 1998, 64:3607-36I4.

31. Kim HK, Park SY, Lee JK, Oh TK: Gene cloning and characterization of thermostable lipase from Bacillus. Stearothermophilus LI. Biosci Biotechnol Biochem 1998, 62:66-7I.

32. Sobek H, Görisch H: Further kinetic and molecular characterization of an extremely heat stable carboxylesterase from the thermoacidophilic archaebacterium Sulfolobus acidocaldarius. Biochem J 1989, 26 I:993-998.

33. Alvarez ME, Augier MV, Baratti J: Characterization of a thermostable esterase activity from the moderate thermophile Bacillus licheniformis. Biosci Biotechnol Biochem 1999, 63:1865-1870.

34. Choi YJ, Miguez CB, Lee BH: Characterization and heterologous gene expression of a novel esterase from Lactobacillus casei CL96. Appl Environ Microbiol 2004, 70:32 I3-322I.

35. Bradford MM: $A$ rapid and sensitive method for the quantitation of microgram quantities of protein utilizing the principle of protein-dye binding. Anal Biochem 1976, 72:248-254.

36. Laemmli UK: Cleavage of structural proteins during the assembly of the head of bacteriophage T4. Nature (London) 1970, 227:680-685.

37. Khalameyzer V, Fischer I, Bornscheuer UT, Altenbuchner J: Screening, nucleotide sequence, and biochemical characterization 
of an esterase from Pseudomonas fluorescens with high activity towards lactones. Appl Environ Microbiol 1999, 65:477-482.

38. Wang XK, Geng X, Egashira Y, Sanada H: Purification and characterization of a feruloyl esterase from the intestinal bacterium Lactobacillus acidophilus. Appl Environ Microbiol 2004, 70:2367-2372.

39. Bzymek KP, Holz RC: The catalytic role of glutamate I5I in the leucine aminopeptidase from Aeromonas proteolytica. J Biol Chem 2005, 279:31018-31025.

Publish with Bio Med Central and every scientist can read your work free of charge

"BioMed Central will be the most significant development for disseminating the results of biomedical research in our lifetime. "

Sir Paul Nurse, Cancer Research UK

Your research papers will be:

- available free of charge to the entire biomedical community

- peer reviewed and published immediately upon acceptance

- cited in PubMed and archived on PubMed Central

- yours - you keep the copyright

Submit your manuscript here:

http://www.biomedcentral.com/info/publishing_adv.asp
BioMedcentral 